\title{
IN VITRO ANTAGONISTIC ACTIVITIES OF INDONESIAN MARINE SPONGE AAPTOS AAPTOS AND CALLYSPONGIA PSEUDORETICULATA EXTRACTS AND THEIR TOXICITY AGAINST Vibrio spp.
}

\author{
Rosmiati*)\#, Habsah Mohamad ${ }^{* *}$, Tengku Sifzizul Tengku Muhammad ${ }^{* * *}$, Najiah Musa***), \\ Aziz Ahmad ${ }^{* * *}$, Noraznawati Ismail ${ }^{* * *}$, Farida Mohamad ${ }^{* *}$, and Nurhidayah*) \\ ${ }^{*}$ Research Institute for Coastal Aquaculture \\ **) Institute of Marine Biotechnology, Universiti Malaysia Terengganu, 21030 Kuala Terengganu, \\ Terengganu, Malaysia \\ ${ }^{* * *)}$ Department of Biological Science, Faculty of Science and Technology, Universiti Malaysia \\ Terengganu, 21030 Kuala Terengganu, Terengganu, Malaysia \\ ${ }^{*}{ }^{* * *)}$ Department of Aqua culture and Fishery Science, Faculty of Agrotechnology and Food Science, \\ Universiti Malaysia Terengganu, 21030 Kuala Terengganu, Terengganu, Malaysia
}

(Received 22 June 2011; Accepted 14 September 2011)

\begin{abstract}
Vibriosis is one of diseases which often results in mass mortality of Penaeus monodon larval rearing systems. It attacks shrimp of all stages in zoea, mysis and shrimp postlarva stage. This disease is caused by Vibrio spp, particularly Vibrio harveyi (a luminescent bacterium). Several kinds of antibiotics and chemical material have been used to overcome the disease but they have side effects to environment and human. The searching of bioactive compounds as an alternative treatment has been done for multi purposes. In this study diethyl eter, butanol and aqueous extract of Indonesian sponges Aaptos aaptos and Callyspongia pseudoreticulata were tested for in vitro activity against Vibrio spp. and Vibrio harveyi by using disc diffusion method. The result showed that all extracts of Aaptos aaptos gave a positive antibacterial activity towards those pathogenic bacteria. Meanwhile, only butanol extract of Callyspongia pseudoreticulata obtained to exhibit an antibacterial activity on those pathogenic bacteria. The strong anti-vibrio activity were shown by butanol and aqueous extract of Aaptos aaptos with the minimum inhibitory concentration (MIC) value of 0.313 and $0.625 \mathrm{mg} / \mathrm{mL}$, respectively. Whilst, the butanol extract of Callyspongia pseudoreticulata indicated a low antibacterial activity with the MIC value of $10 \mathrm{mg} / \mathrm{mL}$. Toxicity of those active extracts was evaluated by Brine Shrimp Lethality Test (BST). Interestingly, butanol and aqueous extracts of Aaptos aaptos did not show any toxic effect in Artemia salina larvae up to $8 \times$ MIC $(2.504 \mathrm{mg} / \mathrm{mL}$ and $5.000 \mathrm{mg} / \mathrm{mL})$. It is the first report for the anti-vibrio activity of both Aaptos aaptos and Callyspongia pseudoreticulata. This results suggest that Aaptos aaptos has a potential to be used as a source of alternative compound to vibriosis prevention for mariculture.
\end{abstract}

\section{KEYWORDS: sponge, Aaptos aaptos, Callyspongia pseudoreticulata,} Vibrio spp., and V. harveyi

\# Corresponding author. Research Institute for Coastal Aquaculture, Jl. Makmur Dg. Sitakka No. 129, Maros 90512, Indonesia. Tel.: + 62411371544

E-mail address: emirosmiati@yahoo.com 


\section{INTRODUCTION}

Aquaculture is the fastest growing food sector globally and found to be high protein resource. However, the biggest problem faced by farmers in aquaculture is high post- larvae mortality caused by vibriosis (Lavilla- Pitogo et al., 1998). Among the causative agents of vibriosis is Vibrio harveyi, a luminescent bacterium which often results in mass mortality of Penaeus monodon larval rearing systems (Mariyono et al., 2002). The bacterium infects almost all cultured marine animals such as crustacean, mollusc and fish (Isnansetyo et al., 2009). Crustacean, including shrimp, crab, lobsters and artemia are very susceptible to this opportunistic pathogenic bacterium (Jivaranichpaisal et al., 1994; Karunasagar et al., 1994; Liu et al.,1996; Robertson et al., 1998; Diggles et al., 2000; Soto- Rodriguez et al., 2003; Borne et al.,2007). Cases of this disease is apparently typical for the tropics (Sunaryanto \& Maryam, 1986; Lavilla- Pitogo et al.,1992).

Efforts to overcome these problems have been done by using chemical material such as formalin, malachite green and antibiotics such as chloramphenicol, oxytetracycline, furazolidone and streptomycin (Moriarty, 1999). The use of these treatments in vibriosis disease prevention brings harmful effects as a result from the accumulation of the harmful residues in the shrimp. These chemical materials also may upset the chemical balance in the pond by affecting useful organisms like nitrifying bacteria and kill food organisms in the pond. Since these antibiotics may cause a side effect, these treatments have become less effective. Beside that the presence antibiotics residue could cause shrimp being rejected by importer countries. Based on these problems, some researchers have attempted other alternative methods to control the diseases by using safe natural antibiotics (Tendencia et al.,
2004). Some of mangrove plants, such as Rhizopora $\mathrm{sp}$ and Achantus sp have been proven capable of reducing the bacteria population in brackish water ponds (Ahmad \& Manganpa, 2000). Another plant species, Isotoma longiflora could inhibit the growth of Aeromonas sp and Pseudomonas sp on fish (Suryati, 1993; Suryati \& Hala, 1993).

Marine sponges have been considered as a gold mine during the past 50 years, with respect to the diversity of their secondary metabolites which pronounced pharmacological activities (Astuti et al., 2005). Most bioactive compounds from sponges can be classified as antiinflammatory, antitumor, immunosuppressive or neurosuppressive, antiviral, antimalarial, antibiotics and antifouling (Sipkema et al., 2005). It is suspected that there are about 10,000 species of sponges and it is estimated that 200 species live in coral reef ecosystem of Southeast Asia (Dahuri, 2003). The number of sponge species in Indonesia was estimated about 830 species, nevertheless it has not been used optimally particularly in disease prevention on fishery culture (Sujatmiko, 2000),

In our searching of antibacterial compounds and compounds which are able to increase the expression of scavenger receptor B- 1 against pathogen bacteria and atherosclerosis, we screened 13 methanolic extracts of Indonesian and Malaysian sponge. The result showed that the methanolic extract of Indonesian Aaptos aaptos and Malaysian Aaptos as well as Callyspongia pseudoreticulata gave positive antibacterial activity towards several species of pathogenic bacteria (Rosmiati et al., 2011). The present study, We wish reported the in vitro antibacterial activity of Indonesian Aaptos aaptos (Figure 1) and Callyspongia pseudoreticulata (Figure 2) extracts against Vibrio spp and Vibrio harveyi.

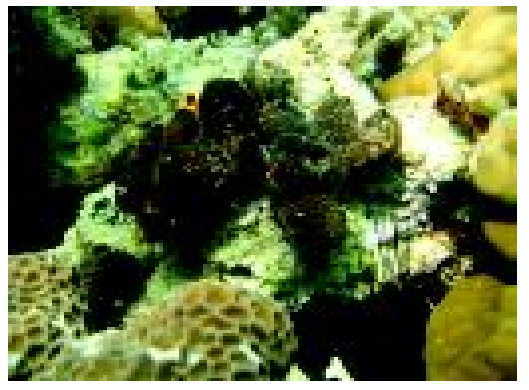

Figure 1. Aaptos aaptos

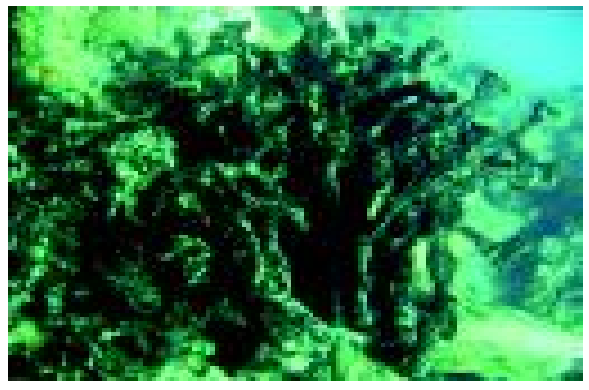

Figure 2. Callyspongia pseudoreticulata 


\section{MATERIALS AND METHODS}

Sponges Aaptos aaptos and Callyspongia pseudor eticulata were collected from Barrang Lompo Islands, South Sulawesi by SCUBA diving at the depth of 10- $12 \mathrm{~m}$ (Figure 3). Sponge was placed in cool box added with ice pack and brought to Biotechnology Laboratory of Research Institute for Coastal Aquaculture (RICA), Maros. The samples were kept in sealed plastic bags then preserved in a freezer at $20^{\circ} \mathrm{C}$. Bioindicator used for testing of antibacterial activity were Vibrio harveyi (1b) and Vibrio spp (2WT) isolated from diseased shrimp collected from Banyuwangi (East Java) and Negara (Bali).

\section{Extraction}

A hundred gram of fresh sponge was cut in small size, dried below $40^{\circ} \mathrm{C}$ and smashed by grinder and repeatedly extracted with methanol by using a forma orbital shaker with the temperature of $37^{\circ} \mathrm{C}$ till the residue was colourless. The methanolic extracts was fil- tered by using a buchener and collected for concentrated under reduce pressure by a rotary evaporator to yield a dark gummy solid (21.4 g for Aaptos aaptos and $10.0 \mathrm{~g}$ for Callyspongia pseudoreticulta).

\section{Removal of salt and lipid/waxes}

HP- 20 resin was activated with methanol and transferred to short glass column with the length of $6.5 \mathrm{~cm}$ and diameter of $1.5 \mathrm{~cm}$. Distilled water was passed through the resin with twice volume of column length. The dried crude methanol extracts was then re- dissolved in distilled water and load onto the resin and eluted by distilled water. The extracts bound by resin were kept out by using methanol. The extracts were concentrated by a rotary evaporator at $37^{\circ} \mathrm{C}$ to get $2 \mathrm{~mL}$ of dried salt free crude methanolic extracts. Two $\mathrm{mL}$ of the salt free methanolic extracts were directly passed through discovery DSC- $186 \mathrm{~mL}$ tube activated with methanol before removing lipid/fat. The extracts were then eluted with methanol to get interference material free extract metha-

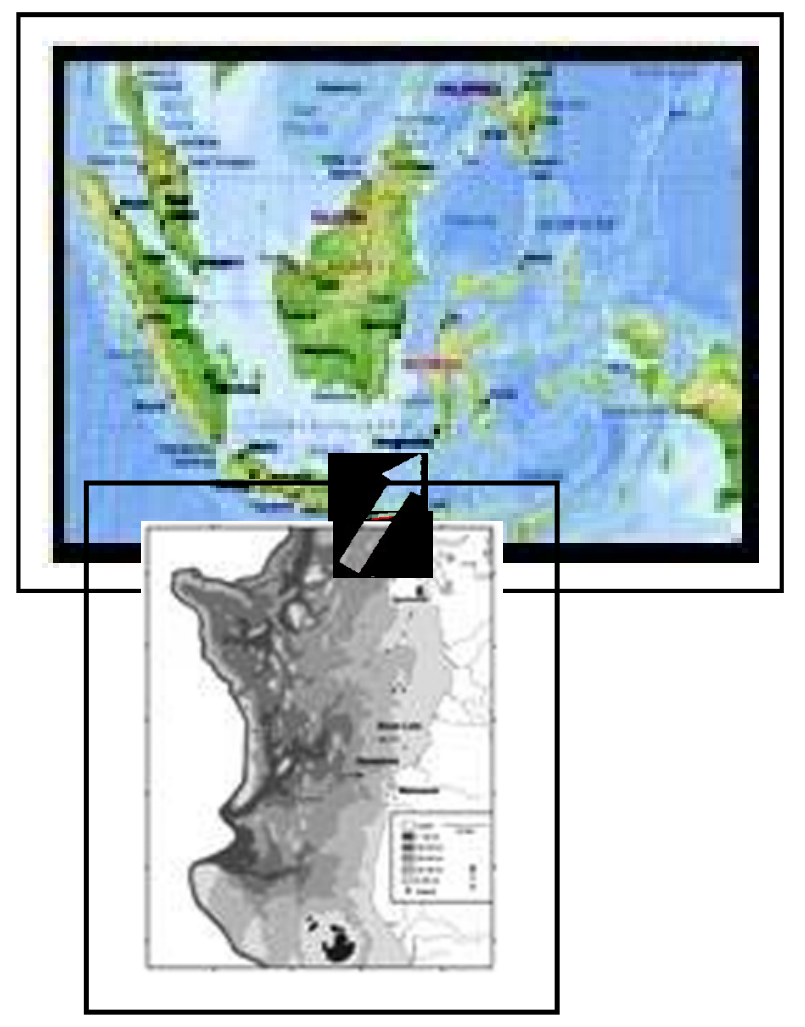

Figure 3. Sample collection sites 
nol. After concentrating the solvent, interference material free crude extracts were obtained and used for the bioassay and partitioning.

\section{Partitioning of methanolic extract}

The interference material free methanolic extract added distilled water and partitioned with diethyl ether (DE) and 1- butanol $(\mathrm{BuOH})$ to give diethyl ether, butanol and aqueous extract. All the extracts were assayed against Vibrio spp. (2WT) and Vibrio harveyi (1b) as described below. The extracts exhibiting an antibacterial activity were again evaluated to determine their minimum inhibitory concentration (MIC) and toxicity.

\section{Antibacterial activity}

The antibacterial activity was tested by using disc diffusion method. Prior to testing, a loopful of Vibrio spp and Vibrio harveyi inoculums was zig-zag streaked on TCBSA (Thiosulfat Citrate Bile Sucr ose Agar) and incubated for 24 hours at $28^{\circ} \mathrm{C}$. One colony of the bacteria growth was sub-cultured in $50 \mathrm{~mL}$ of nutrient broth medium (Sigma, FRG) and incubated for 4 hours using a shaker at $150 \mathrm{rpm}$ and $28^{\circ} \mathrm{C}$ to produce the density of $10^{7} \mathrm{CFU} /$ $\mathrm{mL}$ (Khodria et al., 2011). $100 \mu \mathrm{L}$ of bacteria inoculum were spread on Mueller Hinton agar. The filter paper discs (6 $\mathrm{mm}$ in diameter) were individually impregnated with $20 \mu \mathrm{L}$ of the extracts $(10 \mathrm{mg} / \mathrm{mL})$, dried in a laminar air flow and then placed onto the agar plates previously inoculated with the tested microorganisms. The plates were incubated at $30^{\circ} \mathrm{C}$ for 24 $\mathrm{h}$. The diameters of the inhibition zones were measured in millimetres. All the tests were performed in triplicate. Streptomycin was served as positive controls. The antibacterial activity is interpreted as follow; The diameter of inhibition zone $815.0 \mathrm{~mm}$ - strong; 10,0 to $14.5 \mathrm{~mm}$ moderate and $<10 \mathrm{~mm}$ - weak (Habsah et al., 2007).

\section{Determination of Minimum Inhibitory Concentration (MIC)}

The minimum inhibitory concentration (MIC) of the active fractions against Vibrio spp and $\mathrm{V}$. harveyi was tested by using disc diffusion method as mentioned above. Two-fold dilution of butanol and aqueous extract of Aaptos aaptos and butanol extract of Calyspongia pseudoreticulata from $10 \mathrm{mg} / \mathrm{mL}$ were be used to evaluate their minimum inhibitory concen- tration (MIC). The final concentrations were $5,2.5,1.25,0.625,0.313,0.156$, and 0.078 $\mathrm{mg} / \mathrm{mL}$.

\section{Toxicity testing against the brine shrimp}

Toxicity (bioactive) of the active extract was monitored by the brine shrimp lethality test (Meyer et al., 1982). The active extracts were dissolved in sterilized seawater. Ten of Artemia nauplii hatched for 48 hours were exposed with butanol and aqueous extract of Aaptos aaptos and butanol extract of Callypongia pseudoreticulta at the concentration of 0 (control treatment), 1, 2, 4 and $8 \times$ MIC in triplicate in $20 \mathrm{~mL}$ disposable scintillation vials. The vials were then examined and the number of dead larvae in each bottle after 24 hours was counted and recorded. The mean percentage mortality was counted by equation:

Percentage mortality $(\%)=$

$$
\frac{\text { The number of dead larvae }}{\text { The number of total larvae }} \times 100 \%
$$

\section{Thin Layer Chromatography (TLC) profiling}

All of the active extracts were run on normal phase TLC Silica gel $60 \mathrm{~F}_{254}$ Plastic sheets, Merck as described by Habsah et al. (2007). Mobile phase ratio used was chloroform : methanol $(8: 2)$. Plates were visualized under UV $366 \mathrm{~nm}$ and stained with dragendorf and anisaldehyde- sulfuric acid reagent.

\section{RESULTS AND DISCUSSION}

\section{Results}

\section{The anti- vibrio activity of the extracts of sponge}

The methanolic extracts of Aaptos aaptos and Callyspongia pseudor eticulata were chosen to partitioned based on their antibacterial activity (Rosmiati et al., 2011). Removal of salt and lipid on those methanol extract before being tested for their activity need to be done is due to they came from a saline environment. The extracts resulted in the partitioning were tested for their antibacterial activity against Vibrio spp and Vibrio harveyi with the concentration of $10 \mathrm{mg} / \mathrm{mL}(200 \mu \mathrm{g} /$ disc $)$ each. The anti- vibrio activity was shown in Table 1 . 
Table 1. Inhibition zones ( $\mathrm{mm}$ ) of the active fractions as measured by the disc diffusion method

\begin{tabular}{llcc}
\hline \multirow{2}{*}{$\begin{array}{c}\text { Sponge } \\
\text { species }\end{array}$} & \multicolumn{1}{c}{ Extract } & \multicolumn{2}{c}{ Inhibition zone (mm) } \\
\cline { 3 - 4 } & & $\begin{array}{c}\text { Vibrio spp } \\
(\mathbf{2 W T})\end{array}$ & $\begin{array}{c}\text { Vibrio harveyi } \\
\text { (1b) }\end{array}$ \\
\hline Callyspongia & Methanol & $15 \pm 0.1$ & $17 \pm 0.5$ \\
pseudoreticulata & Diethyl eter & - & - \\
& Butanol & $11 \pm 0.2$ & $11 \pm 0.1$ \\
& Aqueous & - & - \\
Aaptos aaptos & Methanol & $45 \pm 0.5$ & $34 \pm 0.1$ \\
& Diethyl eter & $10 \pm 0.3$ & $9 \pm 0.1$ \\
& Butanol & $23 \pm 0.1$ & $23 \pm 0.1$ \\
& Aqueous & $21 \pm 0.1$ & $22 \pm 0.1$ \\
Control & Streptomycine & $28 \pm 0.1$ & $30 \pm 0.1$ \\
\hline
\end{tabular}

(- ): No inhibition

In general, methanol extract of Aaptos aaptos and Callyspongia pseudoreticulata showed a strong antibacterial activity against Vibrio spp. (2WT) and Vibrio harveyi (1b) with the inhibition zone $15-45 \mathrm{~mm}$. Partitioning on methanol extract of Aaptos aaptos exhibited that all extracts of this sponge were able to inhibit the growth of Vibrio sp (2WT) and Vibrio harveyi (1b). The strong antibacterial activity was shown by the butanol and aqueous extract of this sponge with the inhibition zone of 21-23 mm. Meanwhile that on Callyspongia pseudoreticulata only butanol extract was obtained to give an antibacterial activity towards Vibrio spp. (2WT) and V. harveyi (1b). The antibacterial activity exhibited by butanol extract of Callyspongia pseudoreticulata was similar to that of diethyl eter of Aaptos aaptos. They only were able to give a moderate anti- bacterial activity on both Vibrio spp. (2WT) and Vibrio harveyi (1b).

\section{Determination of minimum inhibitory concentration of the active extracts of sponge}

The minimum inhibitory concentration of the active sponge was determined. In this study, it was obtained the minimum inhibitor concentration of the active extracts of the two sponge used (Figure 4, 5 and 6).

From the figure 4, 5 and 6 , it can be seen that the butanol and aqueous of Aaptos aaptos had MIC values of 0.313 and $0.625 \mathrm{mg} / \mathrm{mL}$, whilst that for the butanol extract of Callyspongia pseudoreticulata was $10 \mathrm{mg} / \mathrm{mL}$. Although all the extracts of Aaptos aaptos had anti-Vibrio activities, the butanol and aqueous

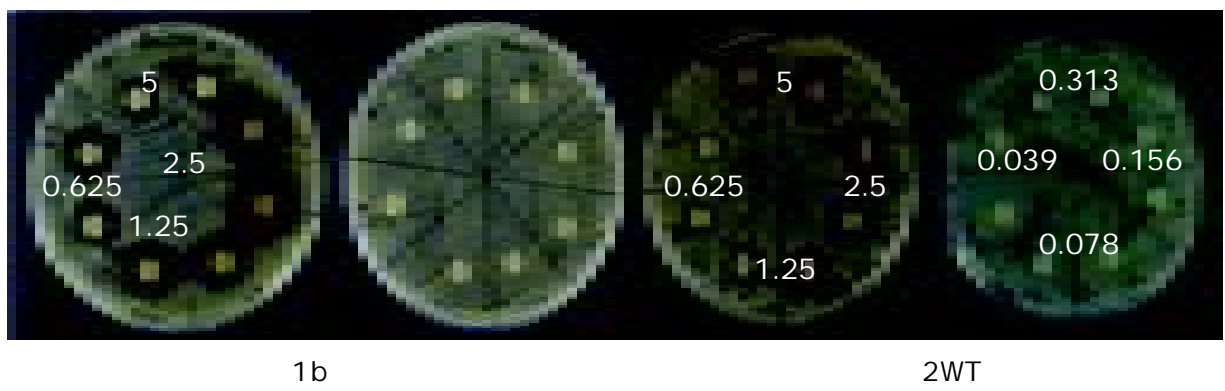

Figure 4. Minimum inhibitory concentration of butanol extract of Aaptos aaptos against Vibrio har veyi (1b) and Vibrio sp (2WT) 


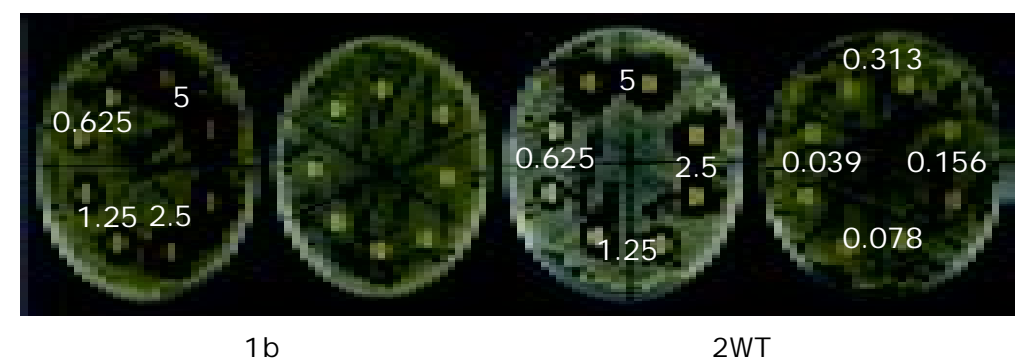

Figure 5. Minimum inhibitory concentration of aqueous extract of Aaptos aaptos against Vibrio harveyi (1b) and Vibrio sp. (2WT)

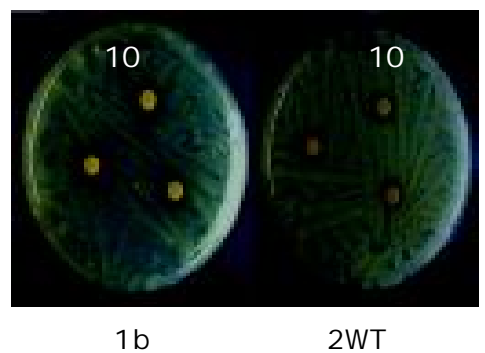

Figure 6. Minimum inhibitory concentration of butanol extract of Callyspongia pseudoreticulata against Vibrio harveyi (1b) and Vibrio sp (2WT)

fraction was more active based on their MIC value. The MIC value showed by butanol extract of Callyspongia pseudoreticulata was the similar to diethyl eter extract of Aaptos aaptos. This study has shown that the active extracts of the two sponges have antagonistic activities against Vibrio species, although the methanol extract appears to be more active.

\section{Toxicity assay using the brine shrimp lethality test (BST)}

The brine shrimp lethality test was conducted on butanol and aqueous extract of Aaptos aaptos and butanol extract of Callyspongia pseudoreticulata. The toxicity of the three extracts indicated by the percentage of mortality of Artemia larvae was shown in Table 2 .

In this study, butanol and aqueous extract of Aaptos aaptos did not show any mortality up to the concentration of $2.5 \mathrm{mg} / \mathrm{mL}$ (8MIC) and $5 \mathrm{mg} / \mathrm{mL}$ (8MIC), respectively. Meanwhile, butanol extract of Callyspongia pseudoreticulata was obtained that there was $30 \%$ mortality of larvae at the concentration of $20 \mathrm{mg} / \mathrm{mL}$ (2MIC).
Thin Layer Chromatography (TLC) profiling of the active extracts of sponge

The TLC profiling of the compounds was shown by Figure 7. The TLC were visualized using UV366 nm, dragendorf and anisaldehydesulfuric acid reagent.

The TLC profiling (Figure 8) showed the presence of alkaloids and other nitrogen containing compounds in the active butanol extract of Aaptos aaptos indicated by orange spots. In contrast there was no those compounds detected in diethyl eter extact of Aaptos aaptos and butanol extract of Callyspongia pseudoreticulata. Nevertheless, the existence of other compounds can be detected by UV $366 \mathrm{~nm}$ and anisaldehide reagent in both diethyl eter extract of Aaptos aaptos and butanol extract of $C$. pseudoreticulata.

\section{Discussion}

This study suggested that sponge Aaptos aaptos has a potential to be used as a source of anti- vibrio compound for vibriosis in mariculture. It was supported by the strong antibacterial activity shown by the active extracts 
Table 2. Percentage of mortality of Artemia salina exposed with butanol and aqueous extract of Aaptos aaptos and butanol extract of Callyspongia pseudoreticulata after 24 hours

\begin{tabular}{ccc}
\hline Extract & $\begin{array}{c}\text { Concentration } \\
(\mathbf{m g} / \mathbf{m L})\end{array}$ & $\begin{array}{c}\text { Percentage of } \\
\text { mortality } \mathbf{( \% )}\end{array}$ \\
\hline Control & $0(0 \mathrm{MIC})$ & 0 \\
BUOH & $0.313(1 \mathrm{MIC})$ & 0 \\
& $0.626(2 \mathrm{MIC})$ & 0 \\
& $1.252(4 \mathrm{MIC})$ & 0 \\
& $2.504(8 \mathrm{MIC})$ & 0 \\
Control & $0(0 \mathrm{MIC})$ & 0 \\
HOEI & $0.625(1 \mathrm{MIC})$ & 0 \\
& $1.250(2 \mathrm{MIC})$ & 0 \\
& $2.500(4 \mathrm{MIC})$ & 0 \\
Control & $5.000(8 \mathrm{MIC})$ & 0 \\
BUEL & $0(0 \mathrm{MIC})$ & 0 \\
& $10.000(1 \mathrm{MIC})$ & 0 \\
& $20.000(2 \mathrm{MIC})$ & $30+0.20$ \\
& $40.000(4 \mathrm{MIC})$ & $100+0.0$ \\
& $80.000(8 \mathrm{MIC})$ & $100+0.0$ \\
\hline
\end{tabular}

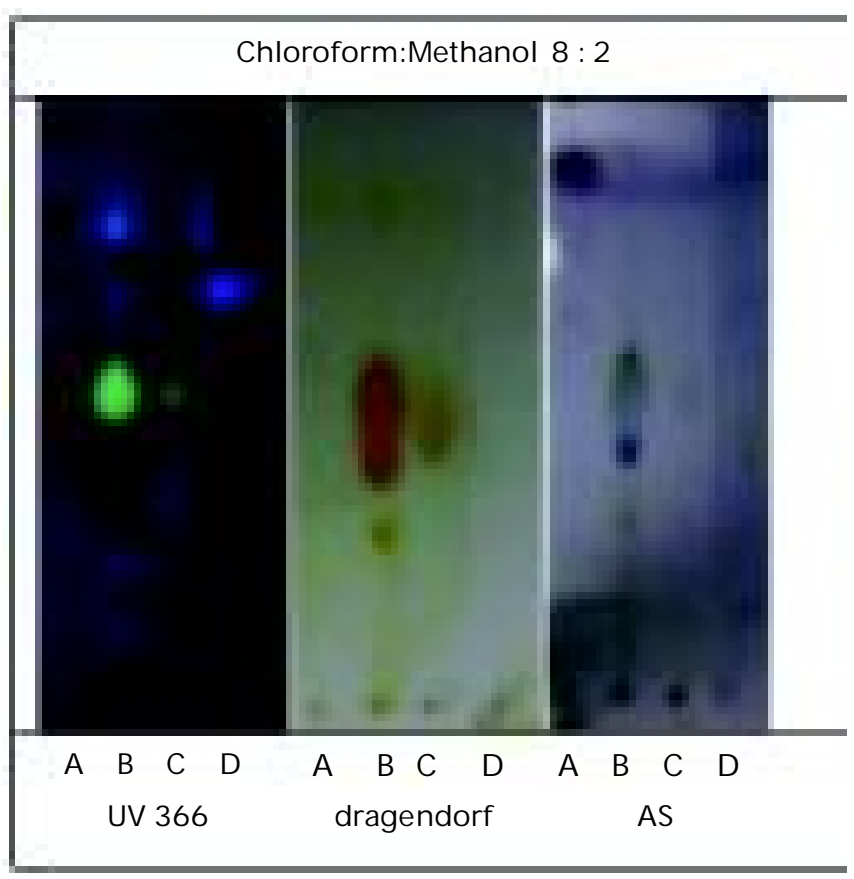

Figure 7. TLC profiling of diethyl eter (A), butanol (B) and aqueous (C) extract of Aaptos aaptos and butanol extract (D) of Callyspongia pseudoreticulata visualized by UV 366, dragendorf and Anisaldehide- sulfuric acid (AS) 
of sponge with the low minimum inhibitory concentration (below $1.6 \mathrm{mg} / \mathrm{mL}$ ). According to Aligiannis et al. (2001), MICs above $1.6 \mathrm{mg} /$ $\mathrm{ml}$ indicate weak activity. In addition the active extract of this sponge did not show any toxic on Artemia salina larvae up to $8 \times$ MIC $(0.313 \mathrm{mg} / \mathrm{mL}$ for butanol extract and 0.625 $\mathrm{mg} / \mathrm{mL}$ for aqueous extract). Moshi et al., 2010 reported that extract or compound having LC $_{50}$ $>100 \mu \mathrm{g} / \mathrm{mL}$ is nontoxic.

Another sponge, Callyspongia pseudoreticulata is a promising candidate to be developed as a raw material source for vibriosis prevention. This may be due to its antagonistic activity against both Vibrio spp (2WT) and V.harveyi (1b).

The anti- vibrio activity shown by butanol and aqueous extract of Aaptos aaptos was suspected due to the presence of alkaloid compounds and other nitrogen containing compounds. According to previous study, marine sponge of the genus Aaptos produces aaptamine which is a $\alpha$ - adrenoceptor blocking compound and is higly toxic to fish. This compound also exhibited an antibacterial activity against Gram- positive and Gram- negative bacteria (Utkina et al., 2009). Nevertheless, aaptamine is not the only one compound which gives the contribution on the antibacterial activity against the target bacteria. The similar case is also obtained in Callyspongia pseudoreticulata. This sponge was reported to yield (3S,18S,4E,16E)- eicosa- I,19- diyne- 3,18diol-4,16-diene which was found to be toxic in the brine shrimp assay (Braekmam et al., 2003; Sonia et al., 2009). In this study, extract of butanol from Callyspongia pseudoreticulata was found to be not toxic to brine shrimp. The strong antibacterial and low/no toxicity to brine shrimp actually of the extracts are good starting points for further research that can lead to the isolation, purification and characterization of active compounds for new antivibrio drug development purposes.

\section{CONCLUSSION}

Indonesian Aaptos aaptos and Callyspongia pseudoreticulata have a potential to be developed for new bioactive compounds for disease prevention in mariculture particularly to vibriosis. It is due to their strong anti- vibrio activity showed by the low minimum inhibitory concentration of 0.313 and $0.625 \mathrm{mg} / \mathrm{mL}$. Furthermore it is nontoxic against Artemia salina with the $\mathrm{LC}_{50}>30 \mathrm{mg} / \mathrm{mL}$.

\section{ACKNOWLEDGEMENT}

The authors thanked the Government of South Sulawesi Province, Indonesia for providing the scholarship and the Ministry of Science, Technology and Innovation (MOSTI), Malaysia for funding research through a Grant no: 53051 and 59161.

\section{REFERENCES}

Ahmad, T. \& Mangampa, M. 2000. The use of mangrove stands for bioremidiation in a close shrimp culture sistem. In Proceeding of International Symposium on Marine Biotechnology, ed. L. Hardjito, p. 114- 120. Jakarta: DFID Press.

Aligiannis, N., Kalpotzakis, E., Mitaku, S., \& Chinou, I.B. 2001. Composition and antimicrobial activity of the essential oils of two Origanum species. Journal of Agricultural and Food Chemistry, 40: 4,1684,170.

Astuti, P., Alam, G., Hartati, M.S., Sari, D., \& Wahyono, S. 2005. Uji sitotoksik senyawa alkaloid dari spons Petrosia sp: potensial pengembangan sebagai antikanker. Majalah Farmasi Indonesia, 16(1): 58- 62.

Bourne, D., Webster, L.Hj,N., Payne, M., Skinderse, M., Givskov, M., \& Hall, M. 2007. Microbiological aspects of phyllosoma rearing of the ornate rock lobster Panulirus ornatus. Aquaculture, 268: 274- 287

Braekman, J.C., Daloze, D., Devijver, C., Dubut, D., \& van Soest, R.W.M.A. 2003. New C- 20 Polyacetylene from the Sponge Callyspongia pseudoreticulata. J. Nat. Prod., 66: 871- 872.

Dahuri, R. 2003. Keanekaragaman Hayati Laut. Penerbit PT Gramedia Pustaka Utama, Jakarta.

Diggles, B.K., Moss, G.A., Carson, J., \& Anderson, C.D. 2000. Luminous vibriosis in rock lobster Jasus verreauxi (Decapoda: Palinuridae) phyllosoma larvae associated with infection by Vibrio harveyi. Dis. Aquat. Organ., 43: 127- 137.

Habsah, M., Zalilawati, M.R., Khozirah, S., Jalifah, L., Lajis, N.H., \&Ali, A.M. 2007. DPPH Free Radical- Scavenging and Antibacterial activities of Methanolic Extracts of Aaptos sp. (Marine sponge) in $12^{\text {th }}$ Asian Chemical Congress (12ACC) in Conjunction with International Symposium on Natural Product and Medical Chemistry, 23- 25 August, Kuala Lumpur, Malaysia. 
Isnansetyo, A., Trijoko, Setyowati, E.P., \& Anshory, H.H. 2009. In vitro antibacterial activity of methanol extract of a sponge, Geodia sp. Against oxytetracyclin- resistent Vibrio harveyi and its toxicity. J. Biol. Sci., 9: 224- 230.

Jivaranichpaisal, P.T., Miyasaki, T., \& Limsuwan, C. 1994. Histopathology, biochemistry and pathogenicity of Vibrio harveyi infecting black tiger prawn Penaeus mondon. J. Aquat. Ann. Health, 6: 27- 35

Karuna Sagar, I., Pai, R., Malathi, G.R., \& Karuna Sagar, I. 1994. Mass mortality of Penaeus mono don larvae due to antibiotic resistant Vibrio harveyi infection. Aquaculture, 128: 203- 209.

Khodria, I., Susianingsih, A.K., Sukenda, E., Yuhana, M., \& Harris, E. 2011. Patogenisitas bakteri Vibrio harveyi yang diisolasi dari lokasi berbeda. In progress.

Lavilla- Pitogo, C.R., Albright, L.J., Poner, M.C., \& Sunaz, N.A. 1992. Studies on the sources of luminescent Vibrio harveyi in Penaeus monodon hatcheries. In: Shariff, I.M., Subasinghe, R.P., \& Arthur, J.R. (eds.), Diseases in Asian Aquaculture I. Fish Health Section, Asian Fisheries Society, Manila, Philippines, p.157- 164.

Lavilla- Pitogo, C.R., Leano, E.M., \& Paner, M.G. 1998. Mortalities of pond-cultured juvenile shrimp Penaeus monodon associated with dominance of luminescent vibrios in the rearing environment. Aquaculture, 164: 337-349.

Lightner, D.V. 1996. A Handbook of Shrimp Pathology and Diagnostic Procedures for Diseases of Cultured Penaeid Shrimp. World Aquaculture Society, Baton Rouge, LA, USA.

Liu, P.C., Lee, K.K., Yii, K.C., Kou, G.H., \& Chen, S.N. 1996. Isolation of Vibrio harveyi from diseased kuruma prawns Penaeus japonicus. Curr. Microbiol., 33: 129- 132.

Mariyono, Wahyudi, A., \&Sutomo. 2002. Teknik penanggulangan penyakit udang menyala melalui pengendalian populasi bakteri di laboratorium. Buletin Teknik Pertanian, 7(1): 25- 27.

Meyer, B.N., Ferrign, R.N., Putnam, J.E., Jacobson, L.B., Nicholas, D.E., \& McLaughlin, J.L. 1982. Brine shrimp: a convenient general bioassay for active plant constituents. Planta Medica, 45: 31- 34.

Moriarty, D.J.W. 1999. Disease Control in Shrimp Aquaculture with Probiotic Bacteria. Micro- bial Biosystems: New Frontiers Proceedings of the 8th International Symposium on Microbial Ecology. In: Bell, C.R., Brylinsky, M., \& Johnson- Green, P. (eds.) Atlantic Canada Society for Microbial Ecology, Halifax, Canada.

Moshii, M.J., Innocenti, E., Otieno, J.N., Magadula, J.J., Nondo, R.S.O., Otieno, A., Wensheit, D.F., \& Mbabazi, P. 2010. Antimicrobial and brine shrimp activity of Acanthus pubescens root extracts. Tanzania Journal of Health Research, 12(2).

Robertson, P.A.W., Calderon, J., Carrera, L., Stark, J.R., Zherdmant, M., \& Austin, B. 1998. Experimental Vibrio harveyi infections in Penaeus vannamei larvae. Dis. Aquat. Organ., 32: 151- 155.

Rosmiati, Habsah, M., \& Muhammad, T.S.T. 2011. Biological activities of methanolic extracts of several sponge species in $10^{\text {th }}$ International Annual Symposium of Universiti Malaysia Terengganu, $11-13^{\text {th }}$ of July 2011 in Kuala Terengganu, Malaysia.

Sipkema, D., Franssen, M.C.R., Osinga, R., Tramper, J., \& Wijffels, R.H. 2005. Marine Sponges as Pharmacy. Marine Biotechnology, 7:142- 163.

Sonia, G.A.S., Lipton, P., \& Raj, P. 2009. Lethal concentration of methanol extract of sponges to the brine shrimp, Artemia salina. J. Mar. Biol. Ass. India, 51(1): 122125.

Soto- Rodriguez, S.A., Roque, A., LizarragaPartida, M.L., Guerra- Flores, A.L., \& GomezGil, B. 2003. Virulence of luminous vibrios to Artemia franciscana nauplii. Dis. Aquat. Organ., 53: 231- 240.

Sujatmiko, W. 2000. Inventarisasi Jenis Spon di sekitar Perairan Pulau Lombok dan Garam di Pulau Sumbawa Nusa Tenggara Barat. Kerjasama : Yayasan Rinjani Bahari, Badan Pengkajian dan Penerapan Teknologi, Badan Perencanaan dan Pembangunan Provinsi Nusa Tenggara Barat.

Sunaryanto, A. \& Mariam, A. 1986. Occurrence of pathogenic bacteria causing luminescent in Penaeid larvae in Indonesia hatcheries. Bull. Brackish Water Aqua. Dev. Cent., 8(2): 64- 70.

Suryati, E. 1993. Bioactivity of Isotoma longiflora on Aeromonas sp. In Proceeding of $30^{\text {th }}$ Faculty of Matematics and Natural Science seminar, ed. M. Kumanireng. Ujung Pandang: Hasanuddin University, p. 15- 17. 
Indonesian Aquaculture Journal Vol.6 No.2, 2011

Suryati, E. \& Hala, Y. 1993. Bioactivity of Isotoma longiflor a on Pseudomonas sp. In: Kumanireng, M. (ed.), Proceeding of $30^{\text {th }}$ Faculty of Matematics and Natural Science Seminar. Hasanuddin University, Ujung Pandang. p. 31- 33.

Tendencia, E.M.R., dela Pena, Fermin, A.C., Lio- Poh, G., Choresia, C.H., \& Inui, Y. 2004. Antibacterial activity of tilapia Tilapia hornorum against Vibrio harveyi. Aquaculture, 32: 145- 152.

Utkina, K., Denisenko, V.A., \&Pushilin, M.A. 2009. Aaptanone, a novel zwitterionic metabolite of the aaptamine class with an oxygenated 1,6- naphthyridine core from the Vietnamese marine sponge Aaptos aaptos. Tetrahedron Letters, 50: 2,580- 2,582. 